\title{
EXPANSION OF THE LIVERWORT TETRALOPHOZIA SETIFORMIS IN THE POLISH TATRA MTS (WESTERN CARPATHIANS)
}

\author{
PIOTR GÓRSKI \\ Department of Botany, August Cieszkowski Agricultural University \\ Wojska Polskiego 71c, 60-625 Poznań, Poland \\ e-mail: peter@au.poznan.pl
}

(Received: April 12, 2006. Accepted: July 19, 2006)

\begin{abstract}
The article presents the spread of the liverwort Tetralophozia setiformis in the Polish Tatra Mts (Western Carpathians). In the years 1814-1957 only four localities of this plant have been found in High Tatra Mts. Since the 90-ties, an increase in recording of $T$. setiformis has been noticed, including the first locality in Western Tatra Mts. Currently, there are 17 localities of T. setiformis in the Polish Tatra Mts. In many of them, the plant occurs abundantly; it also remains in the places of its first records. The species has a narrow ecological scale. It is attached to rock blocks, mostly of north exposition. It creates small, single-species turfs plaited in mossy pillows of alpine grasslands of Oreochloo distichae-Juncetum trifidi racomitrietosum lanuginosi hung among rocks.
\end{abstract}

KEY WORDS: Tetralophozia setiformis, liverworts, rare species, species expansion, Tatra Mts.

\section{INTRODUCTION}

Tetralophozia setiformis (Ehrh.) Schljakov [=Chandonanthus setiformis (Ehrh.) Lindb.] is a subarctic-alpine species (Duell 1983). It has been recorded in Svalbard, Iceland, Norway, Sweden, Finland, Britain, Belgium, Germany, Austria, Czech Republic, Slovakia, Novaya Zemlya, Franz Josef Land, North, Northwest and East Russia, Siberia, Russian Far East, Mongolia, Subarctic America, Western and Eastern Canada, North-Central and North-Eastern USA (Söderström et al. 2002). In Europe, T. setiformis is common in Nordic countries; in the remaining area it occurs in relict localities in higher mountain places (Damsholt 2002). It is considered a highly endangered species in Belgium, Germany and Czech Republic (De Zuttere and Schumacker 1984; Ludwig et al. 1996; Kučera and Váña 2003), and a rare species in Slovakia (Kubinska et al. 1996).

In Poland, Tetralophozia setiformis is found only in the mountains. Ten localities have been recorded in the Sudety Mts (nine in Karkonosze and one in Izerskie Mountains; Szweykowski 1956). In Polish Carpathians, this liverwort is limited to the Tatra Mountains.

The first localities of Tetralophozia setiformis in Tatra Mountains have been documented in the Slovakian Tatra from Kiezmarska Valley (1536 m a.s.l.) already in the 19th century (Wahlenberg 1814 after Szweykowski 1956). Other localities in Slovakian Tatra have been found under the peak of Lomnický štít (Szyszyłowicz 1885), Veĺká Svištovka (Szweykowski 1960; Śmarda 1961; Boros et al.
1960), and from Veĺká Studená Dolina (Duda and Váňa 1982).

In 2006, I confirmed the localities under the peak of Veĺká Svištovka (rock cracks on northern slope, $2000 \mathrm{~m}$ a.s.1., POZNB 523) and on slopes east to the Lomnický štít (1970 m a.s.1., POZNB 524).

On the Polish side of the border, the species have been recorded by Szweykowski $(1956,1957,1960)$ and Wojterski (1957; see the list of localities below). At the same time, Szweykowski (1956) has pointed out that $T$. setiformis is a very rare plant and sparse information on it could not be explained by unsatisfactory level on knowledge on Tatra liverwort flora. So, in 1814-1957 only four localities were known in the Polish Tatra Mountains. There was no information on the species in geobotanical papers published thereafter. However, it should be kept in mind that there were not many hapaticological investigations in that time. In the 80-ties and 90-ies, the research staff of Professor J. Szweykowski from A. Mickiewicz University in Poznań continued gathering data for the flora of Tatra Mountains liverworts. These materials have been deposited in the POZW herbarium and have not been published yet. Since the 90-ties, an increase in records of the species has occurred, including the first locality in Western Tatra. In 2005, I found 10 new localities of Tetralophozia setiformis in High Tatra Mts. The abundance of the plant in new localities, and its localization in high mountain valleys other than those already recorded, indicate that the species starts to spread in the area, or at least the number of its localities increases. 
The aim of this paper is to present the current distribution of Tetralophozia setiformis in Polish Tatra Mts and the characteristics of its localities in habitat-phytocoenosis context.

\section{MATERIAL AND METHODS}

In order to find localities of Tetralophozia setiformis I investigated the whole area of Polish Tatra Mts (High and Western Tatra Mts). The Tatra is the highest mountain range in the whole Carpathians (with Gerlach elevated at $2663 \mathrm{~m}$ a.s.1. in Slovakia and Rysy $2499 \mathrm{~m}$ a.s.1. in Poland). It is a borderline mountain chain situated between Poland and Slovakia, with the greater part belonging to the latter country.

For the majority of new localities I made phytosociological documentation according to the Braun-Blanquet method, with the use of Londo scale for determination of quantitative participation of species (cfr. Dierschke 1994). Location of the studied patches and all geographical names in this paper are given according to the map Tatry Polskie (1992). The names of liverworts are in accordance with the list of Grolle and Long (2000), Ochyra et al. (2003) for mosses, Mirek et al. (2002) for vascular plants, and Fałtynowicz (2003) for lichens.

Herbarium materials were deposited in the herbarium of the Department of Botany, August Cieszkowski Agricultural University in Poznań, Poland (POZNB). Moreover, I studied materials deposited in the Liverworts Laboratory and Herbarium of Adam Mickiewicz University, Poznań (POZW).

\section{RESULTS}

\section{Distribution of Tetralophozia setiformis in Tatra Mts}

Previous localities of $T$. setiformis have been grouped near Żółta Turnia and comprised the northern part of Dolina Gąsienicowa Valley and Dolina Pańszczyca Valley in High Tatra. Complementation of the distribution picture of $T$. setiformis shows a clear concentration of localities in Dolina Gąsienicowa Valley (Fig. 1). The liverwort also occurs in the southern part of the valley (under Orla Perć) and in the cauldron under Świnica. Moreover, I found it in high-located valleys where it has not been recorded so far, i.e. Dolina Waksmundzka Valley and Dolina Pięciu Stawów Polskich Valley. It is clear that the species spreads to the south from the places where it has been recorded first.

I confirmed that $T$. setiformis has stayed in some localities (e.g. in Dolina Pańszczycy Valley) and found new localities near the older ones, especially in sub-peak part of Żółta Turnia, where previously the plant has been recorded on rock shelves at $1660 \mathrm{~m}$ a.s.l., and now it is common in the sub-peak localizations from $1970 \mathrm{~m}$ a.s.l. to the peak (2087 $\mathrm{m}$ a.s.1.).

I did not find Tetralophozia setiformis in the southernmost valleys of the High Tatra - Dolina Rybiego Potoku Valley and Dolina za Mnichem Valley. Despite search I did not confirm the existence of the plant in rubble of Ornak and the mountain range of Liptowska Grań (the Western Tatra).
List of localities

\section{Literature and herbarium data}

The High TAtra Mts, Dolina Gąsienicowa Valley:

1. Dubrawiska, on humus among rock boulders, $1550 \mathrm{~m}$, mass (Szweykowski 1956).

2. North-western precipices of Żółta Turnia, on rock shelves, 1660 m, sparse (Szweykowski 1956).

3. Near western shore of Czarny Staw Gassienicowy Lake, below Przełęcz Karb Pass, on humus among granite boulders, $1625 \mathrm{~m}$ (Wojterski 1957).

4. Near nothern shore of Długi Staw Gąsienicowy Lake, in a tuft with Juncus trifidus (POZW, leg. K. Buczkowska, J. Szweykowski, 22.09.1992).

5. Kocioł Kościelcowy (POZW, leg. J. Szweykowski, 21.08.1959).

THE High TATRA MTS,

DOLINA PAŃSZCZYCA VALLEY:

6. Above Czerwony Stawek, on humus among rock boulders, ca $1700 \mathrm{~m}$ (Szweykowski 1956); locality confirmed in 2005, close to the pond and tourist path, $1660 \mathrm{~m}$, POZNB 521, leg. P. Górski.

THE WESTERN TATRA MTS, DOLINA GORYCZKOWA VALLEY:

7. Below Przełęcz Goryczkowa nad Zakosy Pass, ca 1800 m, rock rubble (POZW, leg. K. Buczkowska, A. Bączkiewicz, 11.08.2002).

\section{New localities}

The High TATRA MTs, Dolina GąsiEnICOWA VALley:

8. In sub-peak part of Żółta Turnia, many localities in altitude range from $1970 \mathrm{~m}$ to the peak $(2087 \mathrm{~m})$; on rock shelves, mass (POZNB 511 and 512, leg. P. Górski, see Table 1, rél. A and B).

9. Above southern shore of Czarny Staw Gąsienicowy Lake, below Kościelec, rock blocks, 1685 m (POZNB 510 and 520, leg. P. Górski, see Table 1, rél. G).

10. Above Zmarzły Staw Gąsienicowy Lake, below Kozia Przełęcz Pass, 1845 m, in two small tufts (POZNB 513, leg. P. Górski, see Table 1, rél. F).

11. Above Czerwone Stawki below Skrajna Turnia, among rock blocks, $1750 \mathrm{~m}$ (POZNB 514, leg. P. Górski, see Table 1, rél. C).

12. Above southern shore of Zadni Staw Gąsienicowy, below Świnica, among rock blocks, $1885 \mathrm{~m}$ (POZNB 515, leg. P. Górski, see Table 1, rél. D).

13. Above north-eastern shore of Zadni Staw Gąsienicowy, below Kościelec, among rock blocks, $1850 \mathrm{~m}$ (POZNB 516, leg. P. Górski, see Table 1, rél. E).

The High Tatra Mts, Dolina Pańszczyca Valley:

14. North to Wielka Kopka, near tourist trail to Przełęcz Krzyżne Pass, rock rubble, 1735 m (POZNB 517, leg. P. Górski).

The High Tatra Mts, Dolina WaKsmundzKa Valley:

15. Above Waksmundzki Potok, on the slope going down from Wołoszyn, below Skrajny Wołoszyn, $1805 \mathrm{~m}$, rock rubble (POZNB 519, leg. P. Górski see Table 1, rél. $\mathrm{H})$. 


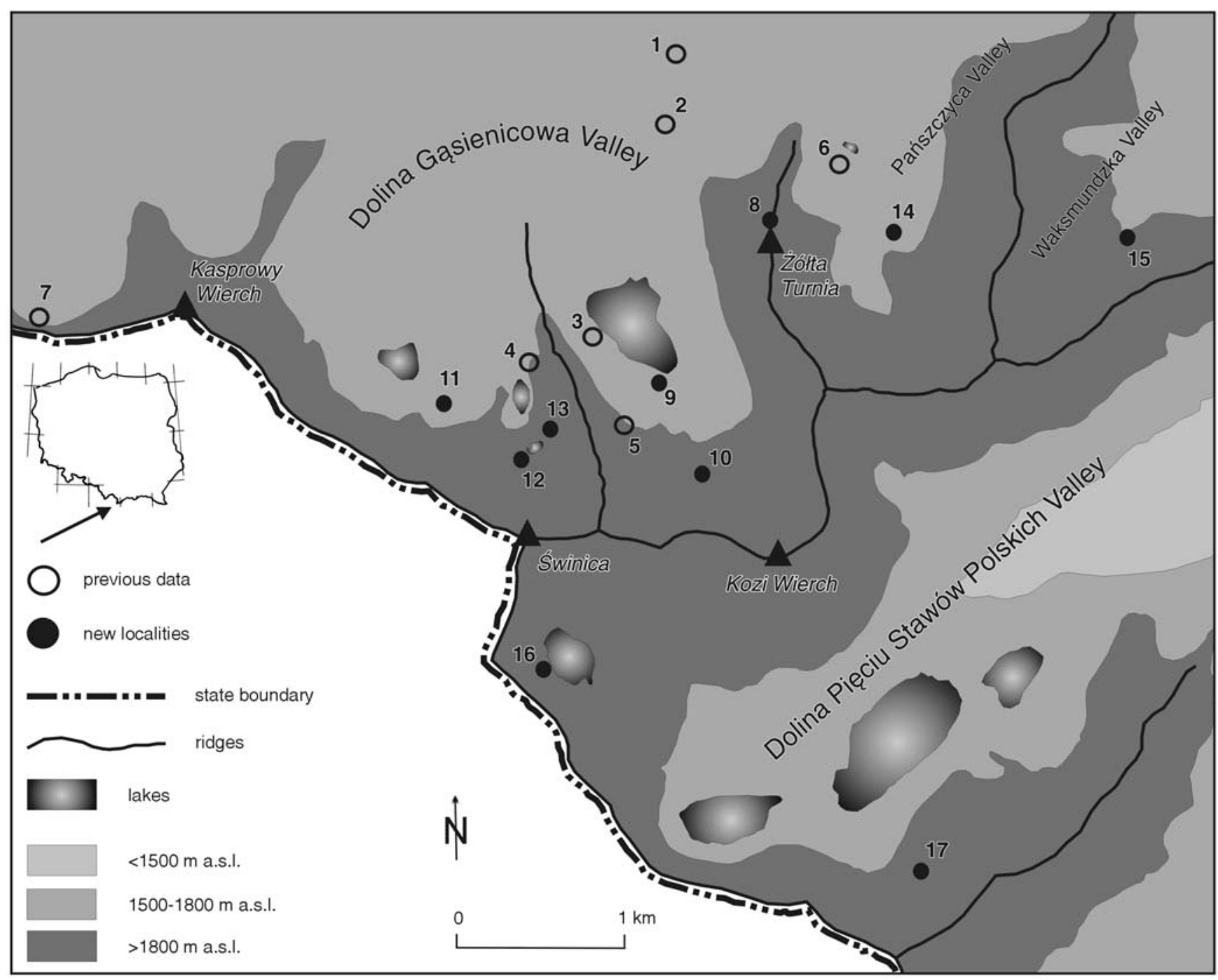

Fig. 1. Distribution of Tetralophozia setiformis (Ehrh.) Schljakov in the Polish part of the Tatra Mts (for detalis of the sites represented by numbers 1-17 see list of localities).

THE High TATRA MTS,

DOLINA PIĘCIU STAWÓW POLSKICH VALLEY:

16. Zadni Piarg, rock rubble going down to southern shore of Zadni Staw, below Walentkowy Wierch, $1880 \mathrm{~m}$ (POZNB 518, leg. P. Górski).

17. Brzuchaty Piarg, above southern shore of Wielki Staw, below Miedziane range, 1910 m, mass (POZNB 522, leg. P. Górski).

\section{Ecology of Tetralophozia setiformis in the Tatra Mts}

Tetralophozia setiformis is an alpine plant connected with acid ground formed in places with granitoid rocks in Tatra Mts. It grows only in the area of rock blocks, on slopes of colder exposure (northern, north-western, and western), in shady places. Exceptionally I noted T. setiformis on coarse scree. $T$. setiformis sprouts flat surface of rock blocks and shelves on which a thin layer of humus develops. Usually the plants form mono-species turfs braided into mossy pillows of alpine grasslands suspended among rocks. In phytosociological depiction, these phytocoenoses represent forms of Oreochloo distichae-Juncetum trifidi Szaf., Pawł. et Kulcz. (1923) 1927 racomitrietosum lanuginosi (Table 1). They are characterized by domination of moss layer including Racomitrium lanuginosum, Polytrichum alpinum, Cetraria islandica, and sporadically, with higher participation, a lichen Alectoria ochroleuca. The herbaceous plant cover is low. Permanent components of this layer are Huperzia selago and Juncus trifidus. The affinity of phytocoenoses with Tetralophozia setiformis to the mentioned type of alpine grassland is without a question. The patches are characterized by small but permanent dash of alpine grassland species of the class Caricetea curvulae Br.-B1. 1948. The community has been previously recorded in High Tatra, Dolina Pięciu Stawów Polskich Valley (Balcerkiewicz 1984), and - as Racomitrietum lanuginosi - in Dolina Temnosmrečinova Valley (Hadač 1956). It is yet widespread in both High and Western Tatra. In the investigated patches I found eight species of liverworts, with the most frequent being Tritomaria quinquedentata, Anastrophyllum minutum, Diplophyllum taxifolium, and Lophozia wenzelii. Among lichens, Cetraria islandica and Cladonia bellidiflora have a high participation in the cover.

Tetralophozia setiformis is a plant attached to habitat conditions of little variety. This causes that the ecology of this species is legible in both habitat and phytocoenotic context. 
TABLE 1. Oreochloo-Juncetum trifidi racomitrietosum lanuginosi with Tetralophozia setiformis from the Polish part of the High Tatra Mts.

\begin{tabular}{|c|c|c|c|c|c|c|c|c|c|}
\hline Succesive number in table & 1 & 2 & 3 & 4 & 5 & 6 & 7 & 8 & $\mathrm{c}$ \\
\hline Number of relevé in the field & $\mathrm{D}$ & $\mathrm{F}$ & $\mathrm{C}$ & $\mathrm{H}$ & $\mathrm{B}$ & A & $\mathrm{E}$ & $\mathrm{G}$ & o \\
\hline Cover of moss layer d [\%] & 90 & 60 & 95 & 100 & 95 & 90 & 75 & 70 & $\mathrm{n}$ \\
\hline Cover of herb layer c [\%] & 5 & 15 & 30 & 80 & 50 & 5 & 5 & 10 & $\mathrm{~s}$ \\
\hline Exposure & $\mathrm{N}$ & & $\mathrm{N}$ & & NW & NW & W & & $\mathrm{t}$ \\
\hline Inclination $\left[{ }^{\circ}\right]$ & 3 & & - & & - & 3 & - & & $\mathrm{a}$ \\
\hline Area of relevé $\left[\mathrm{m}^{2}\right]$ & 0.1 & 0.7 & 0.3 & 0.5 & 0.4 & 0.3 & 0.5 & 0.5 & $\mathrm{n}$ \\
\hline Altitude $[\mathrm{m}]$ & 1885 & 1845 & 1750 & 1805 & 1975 & 1970 & 1850 & 1685 & $\mathrm{c}$ \\
\hline Number of species & 8 & 14 & 11 & 13 & 13 & 11 & 11 & 8 & $\mathrm{y}$ \\
\hline Tetralophozia setiformis & 1 & 1 & 2 & 1 & 2 & 8 & 6 & 4 & V \\
\hline \multicolumn{10}{|l|}{ Ch. Caricetea curvulae } \\
\hline Huperzia selago & .4 & .4 & .1 & . & .2 & .2 & .2 & . & IV \\
\hline Juncus trifidus & . & 1 & 3 & 7 & 5 & . & . & 1 & IV \\
\hline Alectoria ochroleuca & . & . & . & .4 & 6 & 7 & . & . & II \\
\hline Thamnolia vermicularis & . & .2 & . & . & .2 & 2 & .2 & . & III \\
\hline Festuca airoides & . & . & . & .2 & . & .2 & . & . & II \\
\hline Oreochloa disticha & . & . & . & .2 & . & . & .1 & . & II \\
\hline \multicolumn{10}{|l|}{ Others } \\
\hline Racomitrium lanuginosum & .2 & 4 & 3 & .1 & .2 & .2 & 6 & 3 & $\mathrm{~V}$ \\
\hline Polytrichastrum alpinum & 1 & .4 & 1 & .2 & 2 & .4 & 1 & 1 & $\mathrm{~V}$ \\
\hline Cetraria islandica & . & .2 & .2 & 2 & .2 & . & .1 & .2 & IV \\
\hline Cladonia bellidiflora & . & .1 & .1 & .1 & .2 & . & . & .2 & IV \\
\hline Tritomaria quinquedentata & . & 2 & . & . & .2 & . & .1 & .1 & III \\
\hline Anastrophyllum minutum & .2 & . & .1 & .2 & . & .1 & . & . & III \\
\hline Lophozia sudetica & .2 & . & . & . & . & .1 & . & . & II \\
\hline Diplophyllum taxifolium & . & .1 & . & . & .1 & .1 & . & . & II \\
\hline Lophozia wenzelii & . & .2 & . & 1 & & .2 & . & . & II \\
\hline Anastrepta orcadensis & . & . & . & 1 & .1 & . & . & . & II \\
\hline Gymnocolea inflata & .2 & . & . & . & . & . & . & . & I \\
\hline Bazzania tricrenata & .1 & . & . & . & . & . & . & . & I \\
\hline Cladonia gracilis & . & .2 & . & . & . & . & . & . & I \\
\hline Cetraria ericetorum & . & .1 & . & . & . & . & . & . & I \\
\hline Dryptodon contortus & . & .1 & . & . & . & . & . & . & I \\
\hline Cladonia coccifera & . & . & .1 & . & . & . & . & . & I \\
\hline Cladonia furcata & . & . & .1 & . & . & . & . & . & I \\
\hline Stereocaulon vesuvianum & . & . & .1 & . & . & . & & . & I \\
\hline Dicranum scoparium & . & . & . & .2 & . & . & . & . & I \\
\hline Cladonia pleurota & . & . & . & . & .1 & . & . & . & I \\
\hline Cladonia coniocrea & . & . & . & . & . & . & .2 & . & I \\
\hline Pohlia nutans & . & . & . & . & . & . & .1 & . & I \\
\hline Cladonia fimbriata & . & . & . & . & . & . & .1 & . & I \\
\hline Poa laxa & . & . & . & . & . & . & . & .1 & I \\
\hline
\end{tabular}

\section{DISCUSSION}

What are the reasons of the increase in the number of localities of Tetralophozia setiformis in the investigated area? Insufficient level of examination of Tatra hepaticoflora has to be excluded, because Szweykowski (1956) focused his studies on revealing all localities of this plant in the Tatra Mts. At present - like earlier (Szweykowski 1956) - T. setiformis in Tatra does not create sporophytes and does not proliferate by gemmae. A possible way of propagation is fragmentation of gametophores and transmission of their parts by the wind or animals. The gametophores may crush, which is favored by leaves divided into lobes and frequent parching of turfs suspended among rock blocks, a highly drained ground that does not retain water. This, however, does not explain why the increase in the number of localities in Tatra happens now and has not caused the spread of the species earlier. However, on a local scale, regarding a single alpine valley, this actually may be the reason of increment in the number of localities (e.g. in Dolina Gąsienicowa Valley). Climatologic data from recent deca- des show that after a warm period (1927-1959) there was a cold one in years 1960-1990 (Niedźwiedź 2004). Since the 90-ties, the Tatra climate has been getting warmer, probably due to higher frequency of advection of the air from the Atlantic Ocean (Niedźwiedź 1996). So, records of Tetralophozia setiformis from the 50-ties (Szweykowski 1956, 1957; Wojterski 1957) and the present ones fall on a period of local climate warming. These data should be interpreted carefully; they still do not explain the issue completely.

On the other hand, one can advance a hypothesis on long-distance transmission of spores from the North of Europe, where the sporophytes, although rare, are present (Damsholt 2002). This, however, should have induced an increase in the number of localities of Tetralophozia setiformis in the Sudety and other mountains of Central Europe. A question about factors inducing sporulation in places of compact occurrence of Tetralophozia setiformis still remains, though. Investigation of genetic variability of the Tatra population of $T$. setiformis should allow better explaining the reasons of its spread in the mountains. 


\section{ACKNOWLEDGEMENTS}

I thank Dr. Sławomir Janyszek for valuable discussions during preparation of the manuscript, Dr. Katarzyna Buczkowska for providing access to the materials from Liverworts Laboratory and Herbarium of Adam Mickiewicz University, Poznań (POZW), and Dr. Ryszard Koczura (Adam Mickiewicz University, Poznań) for language assistance.

\section{LITERATURE CITED}

BALCERKIEWICZ S. 1984. Roślinność wysokogórska Doliny Pięciu Stawów Polskich w Tatrach i jej przemiany antropogeniczne. Wyd. Naukowe UAM, Ser. Biologia 25: 1-191. (in Polish with English summary)

BOROS A., ŠMARDA J., SZWEYKOWSKI J. 1960. Bryogeographische Beobachtungen der XII. IPE in der Tschechoslowakei. Veröff. Geobot. Inst. Rübel Zürich 36: 119-144.

DAMSHOLT K. 2002. Illustrated Flora of Nordic Liverworts and Hornworts. Nord. Bryol. Soc., Lund, pp. 838.

DE ZUTTERE P., SCHUMACKER R. 1984. Bryophytes nouvelles, méconnues, rares, menacées ou disparues de Belgique. Minist. Region Wallone, Serv. Conserv. Nature, Trav. 13: 1-160.

DIERSCHKE H. 1994. Pflanzensoziologie. Grundlagen und Methoden. Verlag Eugen Ulmer, Stuttgart, pp. 683.

DUDA J., VÁŇA J. 1982. Rozššření játrovek v Československu. XXXIII. Čas. Slez. Muz. Ser. A, 31: 23-38. (in Czech with German summary)

DUELL R. 1983. Distribution of European and Macaronesian Liverworts (Hepaticophytina). Bryol. Beitr. 2: 1-114.

FAŁTYNOWICZ W. 2003. The lichen and lichenicolous and allied fungi of Poland - an annotated checklist. Biodiversity of Poland 6, Polish Academy of Sciences, Institute of Botany, Kraków, pp. 435.

GROLLE R., LONG D.G. 2000. An annotated check-list of the Hepaticae and Anthocerotae of Europe and Macaronesia. J. Bryol. 22: 103-140.

HADAČ E. 1956. Rostlinná společenstva Temnosmrečinové doliny ve Vysokých Tatrách. Biologicé práce 2 (1): 1-87. (in Slovak with Russian and German summary)

KUBINSKA A., JANOVICOVA K., PECIAR V. 1996. The list of extinct, missing and threatened bryophytes (Bryophyta) of Slovakia (1st version). Biologia 51: 373-380.

KUČERA J., VÁŇA J. 2003. Check- and Red List of bryophytes of the Czech Republic. Preslia 75: 193-222.

LUDWIG G., DÜLL R., PHILIPPI G., AHRENS M., CASPARI S., KOPERSKI M., LÜTT S., SCHULTZ F., SCHWAB G.
1996. Rote Liste der Moose (Anthocerophyta et Bryophyta) Deutschlands. Schriftenreihe für Vegetationskunde 28: 189$-306$.

MIREK Z., PIĘKOŚ-MIRKOWA H., ZAJĄC A., ZAJAC M. 2002. Flowering plants and pteridophytes of Poland - a checklist. Biodiversity of Poland 1, Polish Academy of Sciences, Institute of Botany, Kraków, pp. 442

NIEDŹWIEDŹ T. 1996. Wieloletnia zmienność temperatury powietrza i opadów w Tatrach. In: Przyroda Tatrzańskiego Parku Narodowego a Człowiek, Vol 1, Nauki o Ziemi, Kraków-Zakopane, pp. 161-163. (in Polish with English summary)

NIEDŹWIEDŹ T. 2004. Rekonstrukcja warunków termicznych lata w Tatrach od 1550 roku. In: Rola Małej Epoki Lodowej w przekształcaniu środowiska przyrodniczego Tatr. Prace Geograficzne 197: 56-88. (in Polish with English summary)

OCHYRA R., ŻARNOWIEC J., BEDNAREK-OCHYRA H. 2003. Census Catalogue of Polish Mosses. Biodiversity of Poland 3, Polish Academy of Sciences, Institute of Botany, Kraków, pp. 372.

ŠMARDA J. 1961. Doplněk k Mechům Slovenska V. Biol. práce Slov. Akad. Vied, Bratislava, VII/1: 47-75. (in Slovak with English summary)

SÖDERSTRÖM L., URMI E., VÁŇA J. 2002. Distribution of Hepaticae and Anthocerotae in Europe and Macaronesia. Lindbergia 27: 3-47.

SZWEYKOWSKI J. 1956. Materiały do geografii wątrobowców polskich. II. Chandonanthus setiformis (Ehrh.) Howe w Tatrach Polskich. Acta Soc. Bot. Pol. 25 (4): 603-613. (in Polish with German summary)

SZWEYKOWSKI J. 1957. Stań badań nad florą wątrobowców Tatr. Acta Soc. Bot. Pol. 26 (4): 757-784. (in Polish with English summary)

SZWEYKOWSKI J. 1960. Materiały do flory wątrobowców Tatr. Pr. Kom. Biol. PTPN 21 (3): 3-92. (in Polish with English summary)

SZYSZYŁOWICZ I. 1885. O rozmieszczeniu wątrobowców w Tatrach. Spraw. Kom. Fizyogr. AU 19: 25-125. (in Polish)

Tatry Polskie 1992. Szlaki turystyczne, objaśnienia, znaki umowne, skorowidz nazw do mapy topograficznej w skali 1:10 000, 15 map ["The Polish Tatras. Tourist trails, explanations, conventional signs, index of names to the topographical map, 15 maps"]. Nakładem Wydawnictwa "Czasopisma Wojskowe", Warszawa.

WAHLENBERG J. 1814. Flora Carpathorum Principalium. Götingae, pp. 408.

WOJTERSKI T. 1957. Nowe stanowisko wątrobowca Chandonanthus setiformis (Ehrh.) Howe w Tatrach. Spraw. PTPN, 44/45: 332-333. (in Polish) 